\title{
Clinical Experience with Argatroban for Heparin-Induced Thrombocytopenia in a Large Teaching Hospital
}

\author{
Duane Bates, Sarah Griffin, and Barb Angel
}

\begin{abstract}
Background: Argatroban is a direct thrombin inhibitor approved for the prophylaxis or treatment of thrombosis in patients with heparininduced thrombocytopenia (HIT). The product monograph does not guide clinicians beyond specifying the initial dose of $2 \mu \mathrm{g} / \mathrm{kg}$ per minute (or $0.5 \mu \mathrm{g} / \mathrm{kg}$ per minute for patients with hepatic impairment). Some authors have suggested that in the intensive care unit (ICU) and for patients with acute cardiac disease and those with renal or hepatic dysfunction, this dose may result in a supratherapeutic activated partial thromboplastin time (aPTT).
\end{abstract}

Objectives: To evaluate the efficacy and safety of argatroban in adult patients with suspected HIT in a large teaching hospital, and to review dosing for patients in the ICU, patients with acute cardiac disease, and patients with renal or hepatic dysfunction.

Methods: Charts of patients with suspected HIT who had received argatroban for at least $24 \mathrm{~h}$ between October 1, 2005, and October 1, 2007, at the Foothills Medical Centre, Calgary, Alberta, were examined retrospectively.

Results: Thirty patients met the inclusion criteria, with charts available for review. Of these, $21(70 \%)$ patients had an initial argatroban dose of $2 \mu \mathrm{g} / \mathrm{kg}$ per minute and $4(13 \%)$ had an initial dose of $0.5 \mu \mathrm{g} / \mathrm{kg}$ per minute. The median duration of therapy was 6 days, and the mean dose was $2.14 \mu \mathrm{g} / \mathrm{kg}$ per minute. There were 122 dosage adjustments, the most common change being $0.5 \mu \mathrm{g} / \mathrm{kg}$ per minute, followed by adjustments of 1 and $0.1 \mu \mathrm{g} / \mathrm{kg}$ per minute. Six patients had supratherapeutic aPTT values (above $100 \mathrm{~s}$ ), and none experienced major bleeding.

Conclusions: The results of this study suggest that an initial argatroban dose of $2 \mu \mathrm{g} / \mathrm{kg}$ per minute is appropriate for patients with no hepatic dysfunction. Patients with acute cardiac disease and critically ill patients may require lower doses of argatroban; however no dosage adjustments are required for patients with renal dysfunction.

Key words: argatroban, heparin, thrombocytopenia

Can J Hosp Pharm 2009;62(4):290-297

\section{RÉSUMÉ}

Contexte : L'argatroban est un inhibiteur direct de la thrombine approuvé pour le traitement ou la prophylaxie de la thrombose chez les patients atteints de thrombocytopénie causée par l'héparine (TCH). La monographie du produit ne donne aux cliniciens aucune autre indication que la dose initiale de $2 \mu \mathrm{g} / \mathrm{kg}$ par minute (ou $0,5 \mu \mathrm{g} / \mathrm{kg}$ par minute chez les patients atteints d'insuffisance hépatique). Certains auteurs ont avancé que chez les patients à l'unité de soins intensifs (USI) et chez les patients atteints d'une cardiopathie aiguë ou d'une insuffisance rénale ou hépatique, cette dose pourrait résulter en un temps partiel de thromboplastine activée (aPTT) suprathérapeutique.

Objectifs : Évaluer l'efficacité et l'innocuité de l'argatroban dans le traitement d'une TCH soupçonnée chez les patients adultes d'un important hôpital d'enseignement, et examiner la posologie chez les patients de l'USI, ceux atteints d'une cardiopathie aiguë et ceux souffrant d'insuffisance rénale ou hépatique.

Méthodes : Les dossiers médicaux des patients chez qui l'on soupçonnait une TCH et qui ont reçu l'argatroban durant au moins $24 \mathrm{~h}$ entre le $1^{\text {er }}$ octobre 2005 et le $1^{\text {er }}$ octobre 2007 au Foothills Medical Centre de Calgary, en Alberta, ont été examinés rétrospectivement.

Résultats : Trente patients ont satisfait aux critères d'admissibilité; leurs dossiers médicaux étaient disponibles pour examen. De ces patients, 21 (70\%) ont reçu une dose initiale d'argatroban de $2 \mu \mathrm{g} / \mathrm{kg}$ par minute et $4(13 \%)$ ont reçu une dose initiale de $0,5 \mu \mathrm{g} / \mathrm{kg}$ par minute. La durée médiane du traitement était de 6 jours, et la dose moyenne, de $2,14 \mu \mathrm{g} / \mathrm{kg}$ par minute. On a recensé 122 ajustements de la dose, la variation la plus courante étant de $0,5 \mu \mathrm{g} / \mathrm{kg}$ par minute, suivie de variations de 1 et de $0,1 \mu \mathrm{g} / \mathrm{kg}$ par minute. Six patients ont obtenu des valeurs d'aPTT suprathérapeutiques (au-dessus de 100 s), et aucun n'a eu de saignement majeur.

Conclusions : Les résultats de cette étude suggèrent qu'une dose initiale d'argatroban de $2 \mu \mathrm{g} / \mathrm{kg}$ par minute est appropriée chez les patients ne présentant pas d'insuffisance hépatique. Une dose plus faible d'argatroban pourrait être requise chez les patients atteints d'une cardiopathie aiguë et ceux en phase critique, mais aucun ajustement de la dose n'est requis chez les patients atteints d'insuffisance rénale.

Mots clés : argatroban, héparine, thrombocytopénie

(Traduction par l'éditeur] 


\section{INTRODUCTION}

$\mathrm{H}$ eparin-induced thrombocytopenia (HIT) may occur in up to $5 \%$ of patients treated with unfractionated heparin and $1 \%$ of those treated with low-molecular-weight heparin. ${ }^{1}$ HIT may be suspected in a patient with an unexplained decline in platelet count of $50 \%$ or more from baseline and/or a thrombotic event occurring 5 to 14 days after initiation of heparin. ${ }^{1}$ Although HIT may not develop until several days after initiation of heparin therapy, it may occur within $24 \mathrm{~h}$ in patients who have been exposed to heparin within the previous 90 days. $^{1-3}$ Furthermore, between $13 \%$ and 15\% of all HIT cases present 9 to 40 days after discontinuation of heparin. ${ }^{3}$ HIT predisposes patients to venous and arterial thrombosis and is associated with a mortality rate of $10 \%$ to $30 \% .^{1,4}$ This condition may be treated with a direct thrombin inhibitor, such as argatroban. Argatroban has been available in Canada since 2002 and has been the primary agent used in the former Calgary Health Region (now part of Alberta Health Services) for the prophylaxis and treatment of HIT.

The efficacy and safety of argatroban in HIT and in HIT with thrombosis was demonstrated in 2 prospective, nonrandomized, multicentre studies. ${ }^{4,5}$ In those studies, thrombocytopenia was defined as a platelet count less than $100 \times 10^{\%} / \mathrm{L}$ or a 50\% decline from baseline, excluding all other causes. A positive HIT assay was not required for enrolment in either study. The 2 analyses included a total of 349 patients with HIT and 373 patients with HIT with thrombosis who were treated with argatroban; data for these patients were compared with historical controls. The overall mean dose for the 2 studies was 1.9 $\mu \mathrm{g} / \mathrm{kg}$ per minute for a duration of 5 to 7 days. The increment for titrating argatroban was based on the clinical decision of the investigators. The primary composite end point of all-cause death, all-cause amputation, or new thrombosis was significantly lower for patients with isolated HIT than for controls (relative risk reduction $28 \%$ to $34 \%$ ); however, the difference between drug treatment and control did not reach statistical significance in the HIT with thrombosis arm in either study. ${ }^{6}$ The incidence of new thrombosis was significantly lower among argatroban-treated patients than among historical controls, which led to a relative risk reduction of $44.3 \%$ to $74.8 \% .{ }^{6}$ However, the end points of death and amputation did not differ significantly between argatroban-treated patients and historical controls. ${ }^{4,5}$ Furthermore, major bleeding rates did not differ between these 2 groups.

On the basis of these 2 studies, the manufacturer recommends initiating argatroban at $2 \mu \mathrm{g} / \mathrm{kg}$ per minute for patients with normal hepatic function and $0.5 \mu \mathrm{g} / \mathrm{kg}$ per minute for patients with chronic hepatic impairment (ChildPugh score $>6) .^{7}$ The current product monograph does not include guidelines on dosage titration.
Several reports have suggested that the initial dose recommended in the product monograph is too high. For example, recent literature suggests that an activated partial thromboplastin time (aPTT) of 1.5 to 3 times control can be reached with doses of $1 \mu \mathrm{g} / \mathrm{kg}$ per minute or less in patients without hepatic dysfunction and at doses of less than $0.5 \mu \mathrm{g} / \mathrm{kg}$ per minute in patients who do have hepatic dysfunction. ${ }^{8-14}$ Furthermore, for patients with acute cardiac disease and those in the intensive care unit (ICU), a dose of $2 \mu \mathrm{g} / \mathrm{kg}$ per minute may lead to a supratherapeutic aPTT if liver function is normal, which could potentially increase the risk of hemorrhagic complications. ${ }^{12,13,15-18}$ Others have found the need for dose modifications in patients with renal impairment, ${ }^{14,19-22}$ which contradicts the manufacturer's information.

In this study, a retrospective examination of patients' charts was conducted to evaluate the efficacy and safety of argatroban dosing in adult patients with suspected HIT in a large teaching hospital.

\section{METHODS}

Pharmacy medication records were used to identify adults who had received argatroban for at least $24 \mathrm{~h}$ for suspected HIT with or without thrombosis between October 1, 2005, and October 1, 2007, at the Foothills Medical Centre in Calgary, Alberta. Patients were excluded if they were younger than 18 years of age or were pregnant. The study was approved by the Medical Bioethics Department, Faculty of Medicine, University of Calgary.

A patient was considered critically ill if he or she had been admitted to the ICU. Patients with acute cardiac disease were those who had been admitted to the coronary care unit or to the cardiovascular ICU. Chronic hepatic dysfunction was determined from documentation in either the paper or the electronic chart. The Child-Pugh score was calculated if all required variables were available (international normalized ratio [INR], total bilirubin, albumin, ascites, and encephalopathy). Acute hepatic dysfunction was defined as total bilirubin above $25.5 \mu \mathrm{mol} / \mathrm{L}$, aspartate aminotransferase (AST) above $100 \mathrm{U} / \mathrm{L}$, or alanine aminotransferase (ALT) above $100 \mathrm{U} / \mathrm{L}$ at the time of initiation of argatroban, with no previous history of hepatic dysfunction. ${ }^{22}$ Renal dysfunction was determined on the basis of documentation in the paper or electronic chart and/or creatinine clearance $(\mathrm{CrCl})$ less than $60 \mathrm{~mL} / \mathrm{min}$ according to the Cockroft-Gault equation ${ }^{23}$ or, for patients with body mass index (BMI) above $30 \mathrm{~kg} / \mathrm{m}^{2}$, the SalazarCorcoran equation. ${ }^{24}$ Major bleeding was defined as retroperitoneal or intracranial bleeding, bleeding into a prosthetic joint, decrease in hemoglobin of $20 \mathrm{~g} / \mathrm{L}$ or more, and/or clinically evident bleeding requiring transfusion of 2 units or more of packed red blood cells. ${ }^{4,5}$ All other bleeding was considered minor. 
The primary objective was to determine the initial dosage of argatroban and any incremental dosage adjustments and to review the dosing of argatroban for patients with hepatic and renal dysfunction, for critically ill patients, and for patients with acute cardiac disease. The dosing nomogram used in the former Calgary Health Region (see Appendix 1) was derived from the "Argatroban 911" study. ${ }^{25}$ The safety of therapy was described in terms of the number of supratherapeutic aPTT results documented during therapy and the occurrence of major or minor bleeding.

\section{Data Collection}

The following demographic and baseline laboratory data were collected for each patient: age, sex, weight, height, serum creatinine, results of liver function tests (ALT, AST, $\gamma$-glutamyl transferase, alkaline phosphatase, total bilirubin, INR, aPTT, and albumin), platelet count, presence of ascites, encephalopathy, previous diagnosis of HIT, and results of HIT antibody testing (with PF4 Enhanced enzyme-linked immunosorbent assay [ELISA], GTI Diagnostics, Waukesha, Wisconsin).

The following argatroban-related data were also collected: initial dose $(\mu \mathrm{g} / \mathrm{kg}$ per minute), dose range, number of dose increases and decreases, and mean dosage. Additional clinical information was collected as follows: time to therapeutic aPTT, average daily aPTT while receiving argatroban, any new thrombosis while receiving argatroban, progression of thrombosis or limb amputation during therapy, supratherapeutic aPTT during therapy, occurrence of minor or major bleeding, and death during hospital stay.

\section{Statistical Analysis}

Estimates for the primary and secondary objectives are given as means with corresponding standard deviations or medians with corresponding interquartile ranges as appropriate. Overall and patient-specific mean doses were weighted by the duration of each patient's therapy. Incremental adjustment was defined as the absolute difference between 2 consecutive doses for a given patient. The number of adjustments per day was simply a count of the number of adjustments divided by the duration of therapy.

\section{RESULTS}

We identified 45 patients who received argatroban during the study period. Fifteen patients were excluded: for 1 patient, there was no documentation of argatroban therapy, 7 patients had received argatroban therapy for less than $24 \mathrm{~h}$, and for 7 patients the medical records could not be obtained. Therefore, 30 patients were included in the final analysis (Table 1).

Of the 30 patients, $21(70 \%)$ had an initial argatroban dosage of $2 \mu \mathrm{g} / \mathrm{kg}$ per minute, and $4(13 \%)$ had an initial dosage of $0.5 \mu \mathrm{g} / \mathrm{kg}$ per minute. The remaining 5 patients had an initial dosage of 1 or $5 \mu \mathrm{g} / \mathrm{kg}$ per minute. For $7(23 \%)$ of the patients, there were no dose adjustments. For 23 (77\%) of the patients, at least one dose adjustment was made during therapy (Table 2). A total of 74 dose increases and 48 dose decreases were documented, with adjustments ranging from 0.1 to $2.5 \mu \mathrm{g} / \mathrm{kg}$ per minute (see Figure 1). Among all patients, the most common adjustment was $0.5 \mu \mathrm{g} / \mathrm{kg}$ per minute. Adjustments of 0.1 and $0.2 \mu \mathrm{g} / \mathrm{kg}$ per minute were more frequently

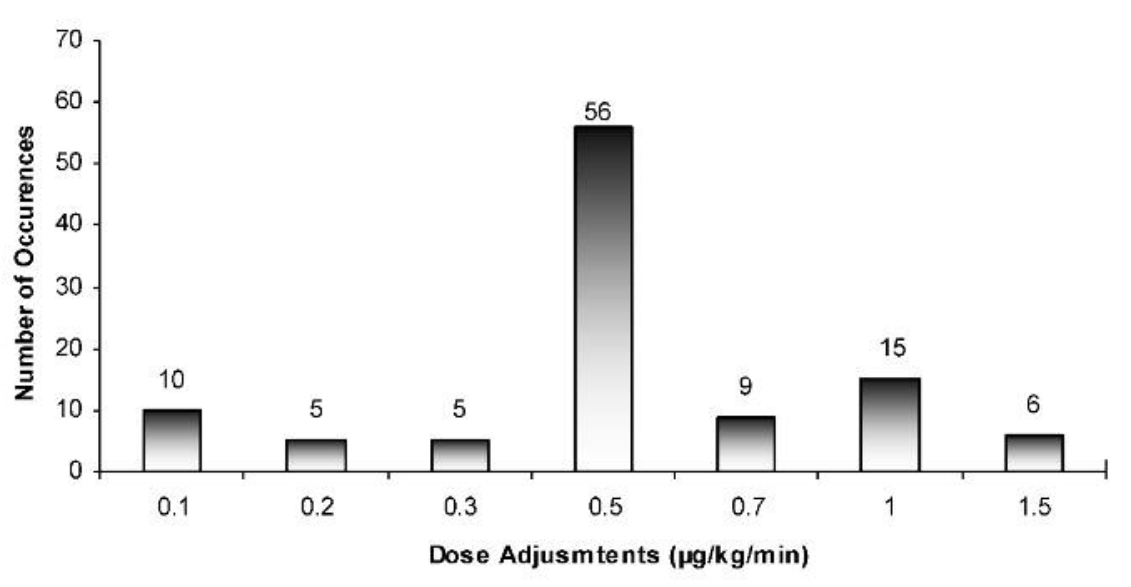

Figure 1. Frequency distribution of dose adjustments, for adjustments with a frequency of at least 5 (where a frequency of 5 is equivalent to $4 \%$ of the 122 dose adjustments for the study patients). The following 16 adjustments (with frequencies less than 5) are not shown in the graph but were included in all other analyses: $1.7-2.5 \mu \mathrm{g} / \mathrm{kg}$ per minute $(n=3), 1.3 \mu \mathrm{g} / \mathrm{kg}$ per minute $(n=3), 0.8 \mu \mathrm{g} / \mathrm{kg}$ per minute $(n=4), 0.6 \mu \mathrm{g} / \mathrm{kg}$ per minute $(n=2)$, $0.4 \mu \mathrm{g} / \mathrm{kg}$ per minute $(n=3), 0.15 \mu \mathrm{g} / \mathrm{kg}$ per minute $(n=1)$. 
Table 1. Baseline Characteristics of Patients

\begin{tabular}{|c|c|c|}
\hline Characteristic & \multicolumn{2}{|c|}{ Data Values } \\
\hline Age, mean \pm SD (years) & \multicolumn{2}{|c|}{$63.5 \pm 15$} \\
\hline \multicolumn{3}{|l|}{ Sex, no. (\%) } \\
\hline Men & 18 & $(60)$ \\
\hline Women & 12 & $(40)$ \\
\hline \multicolumn{3}{|l|}{ Body mass variables } \\
\hline Body weight, mean \pm SD (kg) & \multicolumn{2}{|c|}{$83.8 \pm 17.3$} \\
\hline $\mathrm{BMI}>30$, no. $(\%)$ & & $(33)$ \\
\hline \multicolumn{3}{|l|}{ Coagulation variables } \\
\hline Platelet count, median (IQR) (× 10/L) & & $(33.9-96.5)$ \\
\hline Activated partial thromboplastin time, mean \pm SD (s) & \multicolumn{2}{|c|}{$35 \pm 11.8$} \\
\hline $\mathrm{INR},{ }^{*}$ mean $\pm \mathrm{SD}$ & \multicolumn{2}{|c|}{$1.29 \pm 0.4$} \\
\hline \multicolumn{3}{|l|}{ HIT, no. of patients } \\
\hline Positive test result† & \multicolumn{2}{|l|}{8} \\
\hline History of HIT & \multicolumn{2}{|c|}{$4 \ddagger$} \\
\hline HIT-associated thrombosis & \multicolumn{2}{|c|}{$4 \S$} \\
\hline \multicolumn{3}{|l|}{ Renal function, no. (\%) of patients } \\
\hline $\mathrm{CrCl}>60 \mathrm{~mL} / \mathrm{min}$ & & $(50)$ \\
\hline $\mathrm{CrCl} 30-60 \mathrm{~mL} / \mathrm{min}$ & 9 & (30) \\
\hline $\mathrm{CrCl}<30 \mathrm{~mL} / \mathrm{min}$ & 3 & (10) \\
\hline Hemodialysis & 3 & $(10)$ \\
\hline Hepatic impairment,ๆ median (IQR) & 7 & (23) \\
\hline \multicolumn{3}{|l|}{ Acute impairment ( $n=3$ patients) } \\
\hline ALT (U/L) & 456 & $(277.5-1564.5)$ \\
\hline AST $(U / L)$ & 1195 & $(672.5-1717.5)$ \\
\hline Total bilirubin $(\mu \mathrm{mol} / \mathrm{L})$ & 14 & $(13.5-16.5)$ \\
\hline \multicolumn{3}{|l|}{ Chronic impairment ( $n=4$ patients) } \\
\hline ALT (U/L) & 97 & $(59.5-1485.5)$ \\
\hline AST $(U / L)$ & \multicolumn{2}{|c|}{ Not documented } \\
\hline Total bilirubin ( $\mu \mathrm{mol} / \mathrm{L})$ & \multicolumn{2}{|c|}{$59.5(33.8-105)$} \\
\hline Child-Pugh score & \multicolumn{2}{|c|}{$8 \quad(6.75-9.5)$} \\
\hline \multicolumn{3}{|c|}{$\begin{array}{l}\text { ALT = alanine aminotransferase, AST = aspartate aminotransferase, BMI = body mass index, } \\
\mathrm{CrCI}=\text { creatinine clearance, ELISA = enzyme-linked immunosorbent assay, HIT = heparin-induced } \\
\text { thrombocytopenia, INR = international normalized ratio, IQR = interquartile range, SD = standard } \\
\text { deviation. } \\
\text { *For } 3 \text { patients, INR was not documented at the time of initiation of argatroban. } \\
\text { tFour patients had positive test results with PF4 Enhanced ELISA (GTI Diagnostics, Waukesha, Wisconsin). } \\
\text { Four other patients had equivocal results with ELISA, so samples were sent to McMaster University for } \\
\text { in-house serotonin release assay. } \\
\text { fOne patient with a history of HIT ( } 9 \text { days previously) had a positive result with ELISA. Two patients with } \\
\text { a history of HIT inadvertently received heparin, but neither experienced new thrombosis. } \\
\text { §Includes } 1 \text { patient with a history of HIT who experienced thrombosis after } 24 \text { h administration of } \\
\text { unfractionated heparin; this patient was never tested for HIT. } \\
\text { TIncludes patients with chronic liver impairment and acute changes in liver function. }\end{array}$} \\
\hline
\end{tabular}

\section{Table 2. Dosing Patterns, Stratified by Initial Dose of Argatroban}

Initial Dose of Argatroban; Values for Variables

\begin{tabular}{|c|c|c|c|c|c|c|c|}
\hline \multirow[b]{2}{*}{ Dose Characteristic } & \multirow[b]{2}{*}{$\begin{array}{c}0.5 \mu \mathrm{g} / \mathrm{kg} \\
\text { per minute } \\
(n=4)\end{array}$} & \multirow{2}{*}{\multicolumn{2}{|c|}{$\begin{array}{c}1 \mu \mathrm{g} / \mathrm{kg} \\
\text { per minute } \\
(n=3)\end{array}$}} & \multirow{2}{*}{\multicolumn{2}{|c|}{$\begin{array}{c}2 \mu \mathrm{g} / \mathrm{kg} \\
\text { per minute } \\
(n=21)\end{array}$}} & \multirow{2}{*}{\multicolumn{2}{|c|}{$\begin{array}{c}5 \mu \mathrm{g} / \mathrm{kg} \\
\text { per minute } \\
(n=2)\end{array}$}} \\
\hline & & & & & & & \\
\hline Dose during therapy, mean \pm SD ( $\mu \mathrm{g} / \mathrm{kg}$ per minute) & $0.73 \pm 0.30$ & $1.08=$ & \pm 0.14 & $2.43=$ & \pm 0.81 & 3.70 & \pm 2.26 \\
\hline Duration of therapy, median (range) (days) & $6.5(3-65)$ & 7 & $(4-22)$ & 5 & $(2-20)$ & 17 & $(14-20)$ \\
\hline No. of dose adjustments per patient, median (IQR) & $3.5(0-10.8)$ & 1.0 & $(0.5-4.0)$ & 2.0 & $(1.0-5.0)$ & 7.0 & $(5.5-8.5)$ \\
\hline No. (\%) of patients requiring dose adjustment & $2 \quad(50)$ & 2 & $(67)$ & 17 & $(81)$ & 2 & $(100)$ \\
\hline Total no. of adjustments & 29 & 8 & & 71 & & 14 & \\
\hline No. (\%) increases & (45) & 7 & (88) & 47 & (66) & 7 & (50) \\
\hline No. (\%) decreases & (55) & 1 & $(12)$ & 24 & (34) & 7 & (50) \\
\hline
\end{tabular}

$\mathrm{IQR}=$ interquartile range, SD = standard deviation. 
used for patients with hepatic dysfunction. The mean dose was $2.14 \pm 1.13 \mu \mathrm{g} / \mathrm{kg}$ per minute, and the median duration of therapy was 6 days (range 2-65 days).

Twenty-three $(77 \%)$ of the patients achieved adequate anticoagulation, with a mean aPTT of $59.6 \mathrm{~s}$ (range 35.5$84.6 \mathrm{~s}$ ). The median time to reach therapeutic aPTT was $4 \mathrm{~h}$ (range 2-16.5 h). Achievement of therapeutic anticoagulation was difficult to determine for 5 patients, as the aPTT at initiation of argatroban was greater than $50 \mathrm{~s}$ (mean $56.9 \mathrm{~s}$, range 52.9-59.7 s). One patient never achieved therapeutic aPTT, and another did not undergo aPTT monitoring during therapy. Dosing information, stratified by the patients' medical conditions, is reported in Table 3.

One critically ill patient did not fit the inclusion criteria for any other patient group (i.e., no hepatic or renal dysfunction and no acute cardiac disease). This patient tested positive for HIT, received an initial argatroban dose of $2 \mu \mathrm{g} / \mathrm{kg}$ per minute, and was treated for 9 days. Eight dose adjustments were made ( 4 increases, 4 decreases), and the mean dose was $1.07 \mu \mathrm{g} / \mathrm{kg}$ per minute. Another patient who had undergone cardiovascular surgery did not fit the inclusion criteria for any other patient group. This patient received argatroban $2 \mu \mathrm{g} / \mathrm{kg}$ per minute and was treated for 20 days, despite a negative result on HIT testing. Ten dose adjustments were made ( 4 increases, 6 decreases), and the mean dose was $1.97 \mu \mathrm{g} / \mathrm{kg}$ per minute.

The median dose of argatroban required for patients with either acute or chronic hepatic dysfunction was $1 \mu \mathrm{g} / \mathrm{kg}$ per minute. Only 2 patients with hepatic impairment did not fit the inclusion criteria for any other patient group. Both of these patients had documented chronic hepatic impairment (Child-Pugh scores of 7 and 9, respectively). The initial doses of argatroban were 1 and $2 \mu \mathrm{g} / \mathrm{kg}$ per minute, and the patients were treated for 6 and 22 days, respectively. The patient with the lower starting dose tested negative for HIT, and the patient with the higher starting dose tested positive for HIT. For the patient with the lower starting dose, 5 adjustments were made (4 increases, 1 decrease), and the mean dose was $3.89 \mu \mathrm{g} / \mathrm{kg}$ per minute. For the patient with the higher starting dose, 7 adjustments were made ( 6 increases, 1 decrease), and the mean dose was $1 \mu \mathrm{g} / \mathrm{kg}$ per minute.

Of the 15 patients with renal dysfunction, 9 had creatinine clearance $(\mathrm{CrCl})$ between 30 and $60 \mathrm{~mL} / \mathrm{min}, 3$ had $\mathrm{CrCl}$ below $30 \mathrm{~mL} / \mathrm{min}$, and 3 were undergoing hemodialysis. All 3 of the patients undergoing hemodialysis had an initial argatroban dose of $2 \mu \mathrm{g} / \mathrm{kg}$ per minute. For one of these patients, a dosage increase was applied that resulted in a mean dose of $2.41 \mu \mathrm{g} / \mathrm{kg}$ per minute. Four of the 15 patients with renal dysfunction did not fit the inclusion criteria for any other patient group. Of these 4 patients, 2 had $\mathrm{CrCl}$ between 30 and $60 \mathrm{~mL} / \mathrm{min}, 1$ had $\mathrm{CrCl}$ less than $30 \mathrm{~mL} / \mathrm{min}$, and 1 was undergoing hemodialysis. All 4 of these patients had an initial argatroban dose of $2 \mu \mathrm{g} / \mathrm{kg}$ per minute. One of the patients with $\mathrm{CrCl}$ between 30 and $60 \mathrm{~mL} / \mathrm{min}$ tested positive for HIT, and the other 3 patients tested negative. The patient who was undergoing hemodialysis had an initial argatroban dose of $2 \mu \mathrm{g} / \mathrm{kg}$ per minute and was treated for 5 days with no dose adjustments. The other 3 patients received the drug for 3 to 7 days and required a total of 4 dose adjustments ( 3 increases, 1 decrease); the mean dose for individual patients ranged from 2 to $2.25 \mu \mathrm{g} / \mathrm{kg}$ per minute.

During argatroban therapy, 6 patients experienced elevation of the aPTT (above $100 \mathrm{~s}$ ). The mean supratherapeutic aPTT was $129.7 \mathrm{~s}$ (range 100.5-166.4 s). Three of these patients were critically ill, and 1 patient had undergone cardiovascular surgery. Three of the patients had received an initial dose of $2 \mu \mathrm{g} / \mathrm{kg}$ per minute; another patient had had a dose increase to $5 \mu \mathrm{g} / \mathrm{kg}$ per minute. The other 2 patients were not critically ill, did not have renal or hepatic impairment, and had not been admitted to the coronary care unit or the cardiovascular ICU. For both of these patients, the initial dose was

\section{Table 3. Dosing of Argatroban Stratified by Medical Condition}

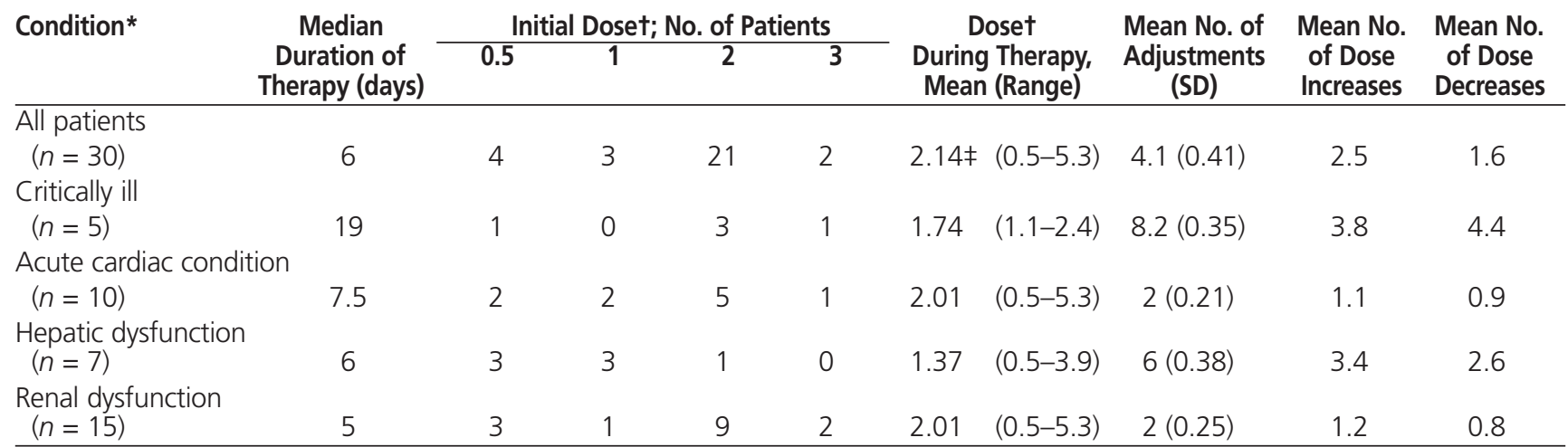

$\mathrm{SD}=$ standard deviation.

*The groupings by medical condition are not mutually exclusive. For example, a patient with both hepatic and renal impairment might have been admitted to the intensive care unit; data for this patient would appear in 3 rows of the table.

tAll dosages are given in micrograms per kilogram per minute.

¥Mean dose could not be calculated for one patient because of poor documentation in the chart. 
$2 \mu \mathrm{g} / \mathrm{kg}$ per minute, and the aPTT reached 120.7 and $135 \mathrm{~s}$, respectively. No cases of major bleeding occurred during argatroban therapy.

No cases of new thrombosis or limb amputation occurred during argatroban therapy. One patient experienced progression of deep vein thrombosis to pulmonary embolism, with a therapeutic aPTT during argatroban therapy (56.7 s, baseline $24.4 \mathrm{~s}$ ). Another patient, who had been admitted with non-ST elevated myocardial infarction, died while in hospital. This patient had been treated with argatroban for suspected HIT for 7 days but tested negative for HIT. The argatroban was discontinued, and the patient died 8 days later of cardiac complications.

\section{DISCUSSION}

For the prophylaxis or treatment of thrombosis in HIT, the recommended initial dose of argatroban is $2 \mu \mathrm{g} / \mathrm{kg}$ per minute, unless patients have moderate hepatic impairment (Child-Pugh score $>6$ or total serum bilirubin $>25.5 \mu \mathrm{mol} / \mathrm{L}$ ), in which case the recommended initial dose is reduced to $0.5 \mu \mathrm{g} / \mathrm{kg}$ per minute. ${ }^{1,722}$ The literature suggests that a lower dose may be required for patients who have undergone cardiac surgery and for those with multiple organ system failure, heart failure, severe anasarca, or conditions associated with hepatic congestion. ${ }^{1,26,27}$ The most common causes of hepatic congestion are volume overload and any cause of right-sided heart failure (constrictive pericarditis, mitral stenosis, tricuspid regurgitation, cor pulmonale, or cardiomyopathy). ${ }^{26,28}$ Recent reports of argatroban use for a variety of clinical indications and in various clinical settings have reported lower doses (0.5$1.2 \mu \mathrm{g} / \mathrm{kg}$ per minute) to achieve target aPTT.

The evidence suggests that critically ill patients may require lower doses of argatroban. Small studies and case series of 4 to 65 patients have reported maintenance doses of 0.125 to $0.91 \mu \mathrm{g} / \mathrm{kg}$ per minute. ${ }^{171,18,20,29}$ Conversely, initial infusions of 1.5 to $2 \mu \mathrm{g} / \mathrm{kg}$ per minute in these patients have resulted in supratherapeutic aPTTs and bleeding. ${ }^{17.18}$ One group of authors suggested that passive hepatic congestion, accumulation of metabolites, and/or interactions with multiple medications used in the ICU may justify lower dose requirements. ${ }^{20}$ In a retrospective study of 65 ICU patients, ${ }^{29}$ it was noted that significantly lower doses were required to achieve therapeutic aPTT as the number of failed organ systems increased from $1(n=26 ; 1.1 \mu \mathrm{g} / \mathrm{kg}$ per minute $)$ to $2(n=26 ; 0.87 \mu \mathrm{g} / \mathrm{kg}$ per minute) to 3 ( $n=13 ; 0.58 \mu \mathrm{g} / \mathrm{kg}$ per minute) ( $p=0.008)$. Liver failure was present in $3.1 \%$ of the patients in that study. ${ }^{29}$ In the study reported here, critically ill patients had initial doses of 0.5 to $5 \mu \mathrm{g} / \mathrm{kg}$ per minute and required the greatest number of dosage reductions, relative to patients with hepatic or renal dysfunction or acute cardiac disease. These results are consistent with reports of lower dosing of argatroban for critically ill patients.
Because of reduced cardiac output during cardiovascular surgery, cardiac, liver, or kidney function may be transiently impaired for a limited period of time after the procedure. . $^{1,30}$ Decreased hepatic perfusion secondary to hypotension from hypovolemia or lowered systemic vascular resistance after surgery is another proposed mechanism. ${ }^{16}$ The potential for reduction in cardiac output and drug elimination is higher after more complex procedures, such as replacement of a cardiac valve. ${ }^{30}$ Hoffmann and others ${ }^{12}$ reported a median argatroban dose of $0.6 \mu \mathrm{g} / \mathrm{kg}$ per minute (range $0.05-3 \mu \mathrm{g} / \mathrm{kg}$ per minute) in 39 patients after coronary artery bypass grafting. The median ALT was $32.3 \mathrm{U} / \mathrm{L}$ (range 4-11 $450 \mathrm{U} / \mathrm{L}$ ), and median total bilirubin was $18.2 \mu \mathrm{mol} / \mathrm{L}$ (range 5.1-136.8 $\mu \mathrm{mol} / \mathrm{L}$ ). Therapeutic aPTT (45-90 s) generally occurred within $15.6 \mathrm{~h}$ in $85 \%$ of the patients. Overall, 7 of the patients died, but none had a thromboembolic event within a median follow-up period of 10 days; clinically significant bleeding occurred in 4 patients. In a case series of 4 patients with normal liver function tests, initial infusions of 1 or $2 \mu \mathrm{g} / \mathrm{kg}$ per minute after cardiac surgery resulted in supratherapeutic aPTT (exceeding 100 s)..$^{16}$ After cardiopulmonary bypass surgery, initial infusions of 0.8 to $1 \mu \mathrm{g} / \mathrm{kg}$ per minute provided rapid and effective anticoagulation without overshooting aPTT; however, lower mean doses $(0.3-0.4 \mu \mathrm{g} / \mathrm{kg}$ per minute) were eventually required..$^{15}$ In patients requiring renal replacement therapy after cardiac surgery, mean infusion rates of 0.06 to $0.12 \mu \mathrm{g} / \mathrm{kg}$ per minute have been used to achieve aPTT of 50 to $80 \mathrm{s.}^{31}$ In the study reported here, lower doses were not used for any of the patients with acute cardiac disease.

A pharmacokinetic study of argatroban in 5 patients with hepatic dysfunction (Child-Pugh score $>6$ ) suggested a 3-fold increase in half-life and a 4 -fold decrease in clearance, relative to healthy controls. ${ }^{32}$ In an analysis of 16 patients with total bilirubin above $25.5 \mu \mathrm{mol} / \mathrm{L}$, the mean dose was $0.8 \mu \mathrm{g} / \mathrm{kg}$ per minute. ${ }^{22}$ One centre's experience with argatroban revealed a lower maintenance dose $(0.25 \mu \mathrm{g} / \mathrm{kg}$ per minute, range $0.05-0.5 \mu \mathrm{g} / \mathrm{kg}$ per minute) in 4 patients with hepatic dysfunction. ${ }^{14}$ Serum bilirubin above $25.5 \mu \mathrm{mol} / \mathrm{L}$ is suggested to be more predictive of decreased argatroban clearance than elevation of either ALT or AST. ${ }^{22}$ In the study reported here, $86 \%(6 / 7)$ of the patients with liver dysfunction received a starting dose of 0.5 or $1 \mu \mathrm{g} / \mathrm{kg}$ per minute, and no patients required a mean dose less than $0.5 \mu \mathrm{g} / \mathrm{kg}$ per minute. There was no difference between chronic and acute hepatic dysfunction in terms of dose requirements.

Argatroban has been studied in renal dysfunction; however, the effect of renal insufficiency on dosing remains unclear. Guzzi and others ${ }^{33}$ reviewed the effect of renal function on argatroban therapy in 260 patients with no hepatic impairment. Their classification consisted of normal or mild impairment of renal function $(\mathrm{ClCr}>60 \mathrm{~mL} / \mathrm{min} ; n=144)$, 
moderate impairment $(\mathrm{CrCl} 30-60 \mathrm{~mL} / \mathrm{min} ; n=80)$, and severe impairment $(\mathrm{CrCl}<30 \mathrm{~mL} / \mathrm{min} ; n=36)$. Among these 3 groups, there were no significant differences in argatroban dose during therapy (mean $1.9 \pm 1.1 \mu \mathrm{g} / \mathrm{kg}$ per minute), duration of therapy $(7 \pm 6$ days), aPTT $(63 \pm 17$ s), or incidence of major bleeding. A recent review of argatroban in 644 patients with differing degrees of renal function noted that for each $30 \mathrm{~mL} / \mathrm{min}$ decrease in $\mathrm{CrCl}$, the therapeutic dose decreased by about 0.1 to $0.6 \mu \mathrm{g} / \mathrm{kg}$ per minute. ${ }^{34}$

Several reports, each describing a small number of patients, have reported the use of argatroban in patients requiring renal replacement therapy. ${ }^{16-19,21,26,31,35-42}$ Dialytic clearance of argatroban with high-flux membranes has been suggested to be clinically insignificant, with systemic clearance increased by about 20\%. ${ }^{36,37}$ Many authors have reported using doses less than $0.5 \mu \mathrm{g} / \mathrm{kg}$ per minute to achieve aPTT of 40-80 s, but some of the patients were critically ill, with acute changes in liver function or recent cardiovascular surgery, or they may have had volume overload, with subsequent hepatic congestion. These conflicting reports create confusion for clinicians who are attempting to initiate argatroban in patients with renal impairment. In the study reported here, renal dysfunction (including hemodialysis) did not appear to affect dosage, as the mean dose used during therapy was $2.01 \mu \mathrm{g} / \mathrm{kg}$ per minute.

This study was limited by its retrospective design, the small sample size, and potential confounding factors. One of the most important limitations of a chart review is incomplete or inaccurate documentation of pertinent information. For example, the adjustments to argatroban dose were based on the patient's weight as entered by the nurse into the Guardian intravenous pump (Baxter Canada); however, this value may have been slightly different from the weight used at the time argatroban was initiated (i.e., the weight may have been rounded up or down or the patient's weight may have changed in the interim). This discrepancy may explain the slight variation between adjustments reported in patients' charts and those specified in the argatroban nomogram used by the former Calgary Health Region.

\section{Conclusions}

The results of this retrospective analysis, in conjunction with the literature, suggest that $2 \mu \mathrm{g} / \mathrm{kg}$ per minute is an appropriate argatroban dose for patients without hepatic impairment or congestion. In acute and chronic hepatic dysfunction, a dose of $0.5 \mu \mathrm{g} / \mathrm{kg}$ per minute is acceptable. A review of the evidence suggests that critically ill patients and patients with acute cardiac disease may be started on a lower dose $(0.5-1 \mu \mathrm{g} / \mathrm{kg}$ per minute), depending on the clinical scenario. In this study, there were no patients with renal impairment who required a reduction in dose, although evidence from other studies suggests that dose reductions may be needed. Clinical judge- ment plays a vital role in determining the initial dosing of argatroban. Depending on the aPTT result, an adjustment of 0.5 to $1 \mu \mathrm{g} / \mathrm{kg}$ per minute is appropriate for most patients. For patients with reduced drug clearance, an adjustment of 0.1 or $0.2 \mu \mathrm{g} / \mathrm{kg}$ per minute may be more appropriate.

\section{References}

1. Warkentin TE, Greinacher A, Koster A, Lincoff AM. Treatment and prevention of heparin-induced thrombocytopenia: American College of Chest Physicians Evidence-Based Clinical Practice Guidelines (8th edition). Chest 2008;133(6 Suppl):340S-380S.

2. Warkentin TE, Kelton JG. Temporal aspects of heparin-induced thrombocytopenia. N Engl J Med 2001;344(17):1286-1292.

3. Dager WE, Dougherty JA, Nguyen PH, Militello MA, Smythe MA. Heparin-induced thrombocytopenia treatment options and special considerations. Pharmacotherapy 2007;27(4):564-587.

4. Lewis BE, Wallis DE, Berkowitz SD, Matthai WH, Fareed J, Walenga JM, et al. Argatroban anticoagulation therapy in patients with heparininduced thrombocytopenia. Circulation 2001;103(14):1838-1843.

5. Lewis BE, Wallis DE, Leya F, Hursting MJ, Kelton JG. Argatroban anticoagulation in patients with heparin-induced thrombocytopenia. Arch Intern Med 2003;163(15):1849-1856.

6. Greinacher A, Warkentin TE. Recognition, treatment, and prevention of heparin-induced thrombocytopenia: review and update. Thromb Res 2006;118(2):165-176.

7. Argatroban product monograph. Kirkland (QC): Pfizer Canada Inc; 2009 Jan.

8. Bartholomew JR, Pietrangeli CE, Hursting MJ. Argatroban anticoagulation for heparin-induced thrombocytopenia in elderly patients. Drugs Aging 2007;24(6):489-499.

9. Kodityal S, Nguyen PH, Kodityal A, Sherer J, Hursting MJ, Rice L. Argatroban for suspected heparin-induced thrombocytopenia: contemporary experience at a large teaching hospital. J Intensive Care Med 2006;21(2):86-92.

10. Kiser TH, Jung R, MacLaren R, Fish DN. Evaluation of diagnostic tests and argatroban or lepirudin therapy in patients with suspected heparininduced thrombocytopenia. Pharmacotherapy 2005;25(12):1736-1745.

11. Rice L, Hursting MJ, Baillie M, McCollum DA. Argatroban anticoagulation in obese versus nonobese patients: implications for treating heparin-induced thrombocytopenia. J Clin Pharmacol 2007;47(8):1028-1034.

12. Hoffmann WD, Czyz Y, McCollum DA, Hursting MJ. Reduced argatroban doses after coronary artery bypass graft surgery. Ann Pharmacother 2008;42(3):309-316.

13. Samuels LE, Kohout J, Casanova-Ghosh E, Hagan K, Garwood P, Ferinand F, et al. Argatroban as a primary or secondary postoperative anticoagulant in patients implanted with ventricular assist devices. Ann Thorac Surg 2008;85(5):1651-1655.

14. Yeo EL, Hicks L, Huh L. Experience with argatroban dosing for heparin induced thrombocytopenia at a large tertiary teaching hospital [abstract]. Blood 2003;102(11):128b.

15. Koster A, Buz S, Hetzer R, Kuppe H, Breddin K, Harder S, et al. Anticoagulation with argatroban in patients with heparin-induced thrombocytopenia antibodies after cardiovascular surgery with cardiopulmonary bypass: first results from the ARG-E03 trial. $J$ Thor Cardiovasc Surg 2006;132(3):699-700.

16. Reichert MG, MacGregor DA, Kincaid EH, Dolinski SY. Excessive argatroban anticoagulation for heparin induced thrombocytopenia. Ann Pharmacother 2003;37(5):652-654.

17. Williamson DR, Boulanger I, Tardif M, Albert M, Gregoire G. Argatroban dosing in intensive care patients with acute renal failure and liver dysfunction. Pharmacotherapy 2004;24(3):409-414.

18. Beiderlinden M, Treschan TA, Görlinger K, Peters J. Argatroban anticoagulation in critically ill patients. Ann Pharmacother 2007;41(5):749-754.

19. Arpino PA, Hallisey RK. Effect of renal function on pharmacodynamics of argatroban. Ann Pharmacother 2004;38(1):25-29.

20. Baghdasarian SB, Singh I, Militello MA, Bartholomew JR, Begelman SM. Argatroban dosage in critically ill patients with HIT [abstract]. Blood 2004;104(11):493a. 
21. Schusterschitz N, Bellman, Stein M, Dunzendorfer S, Pechlaner C, Joannidia M. Influence of continuous veno-venous hemofiltration on argatroban clearance in a patient with septic shock. Intensive Care Med 2008;34(7):1350-1351.

22. Levine RL, Hursting MJ, McCollum D. Argatroban therapy in heparininduced thrombocytopenia with hepatic dysfunction. Chest 2006; 129(5):1167-1175.

23. Cockcroft DW, Gault MH. Prediction of creatinine clearance from serum creatinine. Nephron 1976;16(1):31-41.

24. Salazar DE, Corcoran GB. Predicting creatinine clearance and renal drug clearance in obese patients from estimated fat-free body mass. Am J Med 1988;84(6):1053-1060.

25. Verme-Gibboney CN, Hursting MJ. Argatroban dosing in patients with heparin-induced thrombocytopenia. Ann Pharmacother 2003;37(78):970-975.

26. Athar U, Husain J, Hudson J, Lynch J, Gajra A. Prolonged half-life of argatroban in patients with renal dysfunction and antiphospholipid antibody syndrome being treated for heparin induced thrombocytopenia. Am J Hematol 2008;83(3):245-246.

27. Kubiak DW, Szumita PM. Extensive prolongation of aPTT with argatroban in an elderly patient with improving renal function, normal hepatic enzymes and metastatic lung cancer. Ann Pharmacother 2005;39(6):1119-1123.

28. Friedman LS. Congestive hepatopathy. Waltham (MA): UpToDate [database online, version 16.1]; [updated 2007 Dec 20; cited 2008 May 28]. Available from http://www.uptodateonline.com (subscription required to access content).

29. Begelman SM, Baghdasarian SB, Singh IM, Miitello MA, Hursting MJ, Bartholomew JR. Argatroban anticoagulation in intensive care patients: effects of heart failure and multiple oragan system failure. J Intensive Care Med 2008;23(5):313-320.

30. Dager WE. Considerations for drug dosing post coronary artery bypass graft surgery. Ann Pharmacotherapy 2008;42(3):421-4.

31. Koster A, Hentschel T, Groman T, Kuppe H, Hetzer R, Harder S, et al. Argatroban anticoagulation for renal replacement therapy in patients with heparin induced thrombocytopenia after cardiovascular surgery. J Thorac Cardiovasc Surg 2007;133(5):1376-1377.

32. Swan SK, Hursting MJ. The pharmacokinetics and pharmcodynamics of argatroban: effects of age, gender and hepatic or renal dysfunction. Pharmacotherapy 2000;20(3):318-329.

33. Guzzi LM, McCollum DA, Hursting MJ. Effect of renal function on argatroban therapy in heparin-induced thrombocytopenia. J Thromb Thrombolysis 2006;22(3):169-176.

34. Hursting MJ, Muray PT. Argatroban anticoagulation in renal dysfunction: a literature analysis. Nephron Clin Pract 2008;109(2):80-94
35. Reddy BV, Grossman EJ, Trevino SA, Hursting MJ, Murray PT. Argatroban anticoagulation in patients with heparin-induced thrombocytopenia requiring renal replacement therapy. Ann Pharmacother 2005;39(10):1601-1605.

36. Tang IY, Cox DS, Patel K, Reddy BV, Nahlik L, Trevino S, et al. Argatroban and renal replacement therapy in patients with heparin induced thrombocytopenia. Ann Pharmacother 2005;39(2):231-236.

37. Murray PT, Reddy BV, Grossman EJ, Hammes MS, Trevino S, Ferrell J et al. A prospective comparison of three argatroban treatment regimens during hemodialysis in end-stage renal disease. Kidney Int 2004;66(6):2446-2453.

38. de Denus S, Spinler SA. Decreased argatroban clearance unaffected by hemodialysis in anasarca. Ann Pharmacother 2003;37(9):1237-1240.

39. Dager WE, White RH. Argatroban for heparin-induced thrombocytopenia in hepato-renal failure and CVVHD. Ann Pharmacother 2003;37(9): 1232-1236.

40. Brand PA, Egberts JH, Scholz J, Weiler N, Bein B. Argatroban therapy in patients with hepatic and renal impairment. Eur J Anaesthesiol 2008;25(4):344-346

41. Matsuo T, Wanaka K. Management of uremic patients with heparininduced thrombocytopenia requiring hemodialysis. Clin Appl Thromb Hemost 2007;13(2):182-187.

42. Ota K, Akizawa T, Hirasawa Y, Agishi T, Matsui N. Effects of argatroban as an anticoagulant for hemodialysis in patients with antithrombin III deficiency. Nephrol Dial Transplant 2003;18(8):1623-1630.

Duane Bates, , BSCPharm, ACPR, is Clinical Practice Leader, Medicine in the Department of Pharmacy, Peter Lougheed Centre, Calgary, Alberta.

Sarah Griffin, BSc Pharm, ACPR, is with the Outpatient Pharmacy, Foothills Medical Centre, Calgary, Alberta.

Barb Angel, BSCPharm, ACPR, is with the Pharmacy, Peter Lougheed Centre, Calgary, Alberta.

Address correspondence to:

Duane Bates

Department of Pharmacy

Peter Lougheed Centre

350026 Avenue NE

Calgary AB T1Y 6J4

e-mail: duane.bates@albertahealthservices.ca

\section{Appendix 1. Guideline for Argatroban Dosing Used by the Former Calgary Health Region}

\section{Nomogram for Dosage Adjustments with \\ No Hepatic Dysfunction}

$\mathrm{aPTT}<35 \mathrm{~s}$, increase rate by $1 \mu \mathrm{g} / \mathrm{kg}$ per minute

aPTT 35 to $49.9 \mathrm{~s}$, increase rate by $0.5 \mu \mathrm{g} / \mathrm{kg}$ per minute

aPTT 50 to $84.9 \mathrm{~s}$, maintain at current rate

aPT 85 to $100 \mathrm{~s}$, decrease rate by $0.5 \mu \mathrm{g} / \mathrm{kg}$ per minute

aPTT $>100 \mathrm{~s}$, hold infusion until aPTT $<100 \mathrm{~s}$. Decrease rate

by $50 \%$ (maximum rate $10 \mu \mathrm{g} / \mathrm{kg}$ per minute)

Check aPTT q2-4h; once 3 consecutive therapeutic aPTTs have been recorded, check aPTT once daily

\section{Nomogram for Dosage Adjustment in Hepatic Dysfunction}

aPTT < $35 \mathrm{~s}$, increase rate by $0.2 \mu \mathrm{g} / \mathrm{kg}$ per minute

aPTT 35 to $49.9 \mathrm{~s}$, increase rate by $0.1 \mu \mathrm{g} / \mathrm{kg}$ per minute

aPTा 50 to $84.9 \mathrm{~s}$, maintain at current rate

aPTT 85 to $100 \mathrm{~s}$, decrease rate by $0.1 \mu \mathrm{g} / \mathrm{kg}$ per minute $\mathrm{aPTT}>100 \mathrm{~s}$, hold infusion until aPTT $<100 \mathrm{~s}$ and decrease rate by $50 \%$ (maximum rate $10 \mu \mathrm{g} / \mathrm{kg}$ per minute)

Check aPTT q4-8h; once 3 consecutive therapeutic aPTTs have been recorded, check aPTT once daily 